\title{
PENERAPAN STRATEGI THE FIRING LINE TERHADAP PENINGKATAN KEMAMPUAN PEMAHAMAN KONSEP MATEMATIS SISWA SMP
}

\author{
Selvia Lovita Sari ${ }^{1}$, R. Masykur ${ }^{2}$, Rizki Wahyu Yunian Putra ${ }^{3}$ \\ ${ }^{1,2,3}$ Pendidikan Matematika, Universitas Islam Negeri Raden Intan Lampung \\ E-mail: selvials@yahoo.com ${ }^{1)}$,rmasykur@yahoo.co.id ${ }^{2)}$, \\ rizkiwahyuyp@radenintan.ac.id ${ }^{3)}$
}

Received 8 August 2018; Received in revised form 10 September 2018; Accepted 21 September 2018

\begin{abstract}
The objective in this research is to find out whether the ability to understand student's mathematical concepts with the application of The Firing Line strategy is better than ordinary learning. This research used quantitative research. The method used quasi experiment using pretest- posttest Control Group Design. The population in this study is all students in class VIII SMPN 3 Jati Agung. Sampling used class random technique by lottery technique, obtained class VIII A as experiment class and class VIII B as control class. Based on the results of the $N$-gain hypothesis test the ability to understand mathematical concepts in the material builds up a flat side space (cubes and beams) at signification level $\alpha=0,05$ obtained value $t_{\text {hitung }}=3,783$ and $t_{\text {tabel }}=1,994$. Because $t_{\text {hitung }}>t_{\text {tabel }}$. Its means $H_{o}$ is rejected. Thus, it can be concluded that the ability to understand student's mathematical concepts with The Firing Line strategy is better than ordinary learning models.
\end{abstract}

Keywords: The Firing Line Strategy; Understanding of Concepts.

\section{PENDAHULUAN}

Matematika merupakan sebuah ilmu pasti yang menjadi dasar bagi ilmu lain sehingga matematika itu saling berkaitan dengan ilmu lainnya, dan matematika merupakan salah satu mata pelajaran yang menduduki peranan penting dalam dunia pendidikan (Suwanjal, 2016). Pentingnya ilmu matematika telah dijelaskan didalam AlQuran surah Al. Isra ayat 12. Ayat tersebut menunjukkan bahwa pentingnya ilmu matematika untuk dipelajari dan diterapkan dalam kehiduan sehari-hari yang berguna sebagai alat bantu menyelesaikan persoalan yang memerlukan keterampilan berhitung. Dikehidupan sehari-hari, kita tentu akan menjumpai berbagai persoalan yang berkaitan dengan perhitungan. Mulai dari waktu, pekerjaan, dan uang, semuanya memerlukan perhitungan.

Dalam dunia pendidikan peranan matematika sangatlah penting.
Hal ini karena matematika sebagai sumber ilmu lain, dengan kata lain banyak ilmu yang penemuan dan pengembangannya tergantung dari matematika, sehingga mata pelajaran matematika sangat bermanfaat bagi siswa sebagai ilmu dasar untuk penerapan dibidang lain. Matematika juga memerlukan pemahaman konsep yang baik, karena konsep matematika yang satu dengan yang lainnya saling berkaitan sehingga pemahaman konsep yang dasar merupakan acuan dalam pemahaman konsep selanjutnya.

Menurut Peraturan Menteri Pendidikan Nasional Nomor 22 tahun 2006, salah satu tujuan matematika pada pendidikan menengah adalah agar memiliki kemampuan pemahaman konsep matematika, menjelaskan keterkaitan antar konsep dan mengaplikasikan konsep atau algoritma, secara luwes, akurat, efisien, dan tepat dalam pemecahan masalah (Herawati, 2010). Berdasarkan Permendiknas di 
atas, jika siswa dikatakan mampu memahami konsep dengan baik maka salah satu tujuan pendidikan matematika tersebut akan tercapai. Seorang siswa dikatakan memahami sesuatu apabila dapat memberikan penjelasan atau memberi uraian yang lebih rinci tentang hal itu dengan menggunakan kata-kata sendiri.

Namun pada kenyataannya kemampuan pemahaman konsep matematis siswa masih rendah, terlihat dari hasil nilai uji soal penelitian yang telah dilakukan terkait materi bangun ruang sisi datar masih sangat kurang, banyak siswa masih menjawab soal dengan salah sehingga ada kendala dalam pada saat mengerjakan soal dengan baik dan benar. Hal ini menunjukkan bahwa siswa belum dapat mengaplikasikan konsep bangun ruang sisi datar untuk menyelesaikan masalah yang disajikan dengan tepat serta belum bisa menggunakan prosedur dengan tepat (Wardhani, 2008). Hal ini juga terlihat dari nilai ulangan harian matematika siswa yang belum mencapai KKM (Kriteria Ketuntasan Minimal) yang telah ditetapkan oleh sekolah terhadap kemampuan pemahaman konsep matematis siswa yaitu 70 .

Banyak faktor yang menyebabkan pemahaman konsep matematis rendah yang ditemukan pada penelitian pendahuluan siswa salah satunya bisa berasal dari diri siswa itu sendiri atau dari luar sana. Faktor dari luar yaitu bisa berasal dari dari sarana dan prasarana, media yang digunakan dan cara penyampaian guru pada pembelajaran. Sedangkan dari dalam siswa misalnya kecerdasan, motivasi siswa, cara belajar dan minat yang kurang dari siswa itu sendiri dan menganggap bahwa matematika sebagai mata pelajaran yang sangat sulit dan membosankan yang hanya dipenuhi dengan rumus-rumus dan simbol- simbol yang tidak mereka mengerti dengan pasti (Ningsih : 2014).

Berdasarkan hasil penelitan yang telah dilakukan oleh Kartini (2014) bahwa strategi yang dilaksanakan oleh guru masih bersifat tradisional dan guru lebih dominan berperan dalam pembelajaran sehingga pada proses pembelajaran hanya terjadi komunnikasi satu arah.

Berdasarkan hasil penelitian dari Utari (2012) bahwa pemahaman konsep terhadap siswa masih rendah. Hal ini karena pada proses pembelajaran masih didominasi oleh guru, siswa hanya mendengarkan, mencatat dan mengerjakan tugas yang diberikan oleh guru. Sehingga siswa mengalami kesulitan dalam belajar matematika.

Penelitian Murizal, dkk (2012) bahwa banyak siswa yang kesulitan dalam memahami konsep matematika. Kurang tepatnya model pembelajaran yang digunakan oleh guru dapat menyebabkan mereka kebanyakan tidak mampu mendefenisikan kembali bahan pelajaran matematika dengan bahasa mereka sendiri serta membedakan antara contoh dan bukan contoh dari sebuah konsep apalagi memaknai matematika dalam bentuk nyata. Penelitian Gusliani, dkk (2013) bahwa pemahaman konsep matematis siswa dengan strategi The Firing Line lebih baik, dan diharapkan untuk dapat mencoba menerapkan pembelajaran dengan strategi The Firing Line sebagai salah satu alternatif untuk mencapai tujuan belajar.

Dari penelitian-penelitian yang sudah dijelaskan di atas terlihat bahwa pemahaman konsep siswa terhadap mata pelajaran matematika masih begitu rendah. Hal ini berkemungkinan dipengaruhi oleh strategi yang digunakan guru kurang menarik perhatian siswa. Sehingga dalam proses pembelajaran mereka cenderung pasif,

\section{$230 \mid$ AKSIOMA}


takut, dan enggan untuk bertanya serta mereka lebih memilih untuk diam jika ada sesuatu hal yang belum mereka pahami dari pada harus bertanya kepada guru yang mengajar.

Padahal guru sudah berupaya untuk meningkatkan kemampuan pemahaman konsep matematis, akan tetapi upaya tersebut masih kurang optimal. Hal ini terlihat pada saat proses pembelajaran siswa cenderung diam, hanya mencatat dan mendengarkan penjelasan dari guru (Sudarman, 2016). Sehingga siswa kurang aktif untuk menyampaikan ide-ide yang dimilikinya. Akibatnya pemahaman konsep siswa dalam belajar matematika kurang optimal serta keaktifan siswa dalam proses belajar matematika hampir tidak menonjol. Hal ini disebabkan karena pada proses pembelajaran guru masih sering menggunakan pembelajaran biasa.

Untuk itu, dalam pembelajaran matematika diperlukan suatu strategi yang dapat menimbulkan suasana belajar menjadi lebih menarik serta mengajak siswa untuk ikut aktif dalam pembelajaran, dan menyenangkan siswa dalam proses mengajar, sehingga masing-masing dari siswa dapat memahami konsep materi serta terlibat

\section{METODE PENELITIAN}

Penelitian ini menggunakan penelitian kuantitatif dengan metode penelitian eksperimen semu (Quasy Experimental design). Penelitian ini menggunakan desain pretest-posttest control group design yang akan lebih aktif dalam proses pembelajaran (Rahmawati, 2017). Salah satu strategi yang dapat digunakan untuk meningkatkan keaktifan dan melatih kemampuan pemahaman konsep matematis adalah strategi The Firing Line

Strategi The Firing Line merupakan suatu strategi pembelajaran dengan cara gerakan cepat yang dapat digunakan untuk merespon secara cepat pertanyaan-pertanyaan yang dilontarkan. Melalui pertanyaanpertanyaan yang diberikan antar ini, pembelajaran yang dilaksanakan menjadi pembelajaran interaktif dan membangun kerjasama antar siswa (Silberman, 2014). Dengan adanya pertanyaan-pertanyaan tersebut maka proses pembelajaran berlangsung akan aktif sehingga siswa dapat mengembangkan kemampuan berfikir baik untuk menyusun pertanyaan maupun untuk menyusun jawaban dari pertanyaan yang telah diberikan.

Tujuan penelitian ini adalah untuk mengetahui manakah yang lebih baik peningkatan kemampuan pemahaman konsep matematis siswa dengan penerapan strategi The Firing Line lebih baik dari pembelajaran biasa.

digunakan untuk mengetahui penerapan strategi The Firing Line untuk meningkatkan kemampuan pemahaman konsep matematis siswa (Putra, 2016). Desain penelitian yang digunakan adalah sebagai berikut :

Tabel 1. pretest-posttest control group design

\begin{tabular}{|c|c|c|c|}
\hline Kelompok & Pretest & Treatment & Posttest \\
\hline Kelas Ekperimen & $\mathrm{O}_{1}$ & $\mathrm{X}_{1}$ & $\mathrm{O}_{2}$ \\
\hline Kelas Kontrol & $\mathrm{O}_{3}$ & $\mathrm{X}_{2}$ & $\mathrm{O}_{4}$ \\
\hline
\end{tabular}

Keterangan:

$\mathrm{X}_{1}$ : Pembelajaran dengan menggunakan Strategi The Firing Line 
$\mathrm{X}_{2} \quad$ : Pembelajaran biasa

$\mathrm{O}_{1}$ : Pretest kemampuan pemahaman konsep matematis pada kelas eksperimen

$\mathrm{O}_{2} \quad$ : Posttest kemampuan pemahaman konsep matematis pada kelas eksperimen

$\mathrm{O}_{3}$ : Pretest kemampuan pemahaman konsep matematis pada kelas kontrol

$\mathrm{O}_{4}$ : Posttest kemampuan pemahaman konsep matematis pada kelas kontrol

Variabel pada penelitian ini adalah variabel bebas dan variabel terikat. Variabel bebas dalam penelitian ini adalah strategi pembelajaran The Firing Line. Sedangkan variabel terikat dalam penelitian ini adalah kemampuan pemahaman konsep matematis.

Penelitian ini dilaksanakan di SMP Negeri 3 Jati Agung. Populasi dalam penelitian ini adalah seluruh siswa pada kelas VIII yang berada di SMPN 3 Jati Agung sebanyak 5 kelas dengan jumlah 180 siswa. Pengambilan sampel penelitian ditentukan dengan menggunakan teknik acak kelas dengan teknik undian, dengan diperoleh kelas VIII A sebagai kelas kelas eksperimen dan kelas VIII B sebagai kelas kontrol dengan jumlah siswa pada masingmasing kelas adalah 36 siswa.

Instrumen yang digunakan untuk mengumpulkan data pada penelitian ini ialah tes tertulis berupa soal uraian (essay) yang akan diberikan di awal dan akhir pembelajaran. Pada penelitan ini soal tes terlebih dahulu diuji validitas, reliabilitas, tingkat kesukaran dan daya pembeda.

Teknik analisis data menggunakan uji t dua sampel yang bertujuan untuk mengetahui peningkatan kemampuan pemahaman konsep matematis siswa yang menggunakan strategi pembelajaran The Firing Line. Pada penelitian ini peningkatan kemampuan pemahaman konsep matematis siswa dapat dilihat dari analisis gain yaitu selisih antara nilai pretest dan nilai posttest yang dapat dihitung dengan rumus sebagai berikut

$$
<g>=\frac{S_{\text {Post }}-S_{\text {Pre }}}{S_{\text {Maks }}-S_{\text {Pre }}}
$$

Keterangan

$<g>=N-$ Gain

$S_{\text {Post }}$ : Skor Posttest

$S_{\text {Pre }}:$ Skor Pretest

$S_{\text {Maks }}$ : Skor Maksimum Ideal

\section{HASIL PENELITIAN DAN PEMBAHASAN}

Pada penelitian ini diperoleh data hasil uji coba instrumen, uji test awal (pretest), uji test akhir (posttest), dan data amatan peningkatan kemampuan pemahaman konsep matematis. Sebelum proses pembelajaran dilaksanakan, pada kedua kelas terlebih dahulu diadakan pretest untuk memperoleh data awal. Setelah data dari kelas eksperimen dan kelas kontrol terkumpul maka diadakan uji normalitas dan uji homogenitas untuk mengetahui apakah kedua sampel memiliki variansi homogen. Deskripsi hasil data pretest disajikan pada tabel berikut:

\section{2 | AKSIOMA}


ISSN 2089-8703 (Print) Vol. 7, No. 2 (2018) 229-236

ISSN 2442-5419 (Online)

Tabel 2. Data Hasil Pretest Pemahaman Konsep Matematis

\begin{tabular}{|c|c|c|c|c|c|c|c|}
\hline \multirow{2}{*}{ Kelompok } & \multirow{2}{*}{$\boldsymbol{X}_{\min }$} & \multirow{2}{*}{$\boldsymbol{X}_{\max }$} & \multicolumn{3}{|c|}{$\begin{array}{c}\text { Ukuran Tendensi } \\
\text { Sentral }\end{array}$} & \multicolumn{2}{c|}{$\begin{array}{c}\text { Ukuran } \\
\text { Variansi } \\
\text { Kelompok }\end{array}$} \\
\cline { 4 - 8 } & & & $\overline{\boldsymbol{x}}$ & $\boldsymbol{M}_{\mathbf{0}}$ & $\boldsymbol{M}_{\boldsymbol{e}}$ & $\boldsymbol{R}$ & $\boldsymbol{S d}$ \\
\hline Eksperimen & 12,5 & 62,5 & 38,55 & 37,5 & 37,5 & 50 & 12,84 \\
\hline Kontrol & 12,5 & 62,5 & 35,76 & 29,17 & 33,33 & 50 & 12,37 \\
\hline
\end{tabular}

Berdasarkan Tabel 2 dapat dilihat bahwa nilai rata-rata hasil pretest pemahaman konsep pada kelas eksperimen lebih tinggi daripada kelas kontrol. Rata-rata kelas eksperimen adalah 38,55 dan kelas kontrol 35,76.

Ukuran vaiansi kelompok yang meliputi jangkauan atau rentang untuk kelas eksperimen 50 dan kelas kontrol 50. Simpangan baku kelas eksperimen sebesar 12, 85 dan kelas kontrol sebesar 12,38 .

Setelah selesai dilaksanakannya pembelajaran, pada kedua kelas tersebut diberikan posttest untuk mengetahui data akhir setelah dilaksanakannya proses pembelajaran tersebut. Setelah data posttest dari kelas eksperimen dan dari kelas kontrol terkumpul maka diadakan uji normalitas dan homogenitas. Uji homogenitas dilakukan untuk mengetahui apakah kedua kelas memiliki variansi homogen. Selanjutnya, setelah uji normalitas dan homogenitas terpenuhi, dilanjutkan dengan uji hipotesis menggunakan uji-t untuk mengetahui apakah strategi pembelajaran The Firing Line dapat meningkatkan kemampuan pemahaman konsep matematis siswa. Deskripsi hasil posttest adalahsebagai berikut :

Tabel 3. Data Hasil posttest Pemahaman Konsep Matematis

\begin{tabular}{|c|c|c|c|c|c|c|c|}
\hline \multirow{2}{*}{ Kelompok } & \multirow{2}{*}{$\boldsymbol{X}_{\text {min }}$} & \multirow{2}{*}{$\boldsymbol{X}_{\text {max }}$} & \multicolumn{3}{|c|}{$\begin{array}{c}\text { Ukuran Tendensi } \\
\text { Sentral }\end{array}$} & \multicolumn{2}{c|}{$\begin{array}{c}\text { Ukuran } \\
\text { Variansi } \\
\text { Kelompok }\end{array}$} \\
\cline { 4 - 9 } & & & $\overline{\boldsymbol{x}}$ & $\boldsymbol{M}_{\boldsymbol{o}}$ & $\boldsymbol{M}_{\boldsymbol{e}}$ & $\boldsymbol{R}$ & $\boldsymbol{S \boldsymbol { d }}$ \\
\hline Eksperimen & 66,67 & 95,83 & 81,6 & 70,83 dan 91,67 & 83,33 & 29,16 & 9,42 \\
\hline Kontrol & 58,33 & 91,67 & 75,58 & 70,83 dan 75 & 70,83 & 33,34 & 8,92 \\
\hline
\end{tabular}

Berdasarkan Tabel 3 dapat dilihat bahwa rata-rata nilai posttest kelas eksperimen lebih tinggi dari pada kelas kontrol yaitu 81,6 dan 75,58. Simpangan baku kelas eksperimen sebesar 9,42 dan kelas kontrol sebesar 8,42 .

Pada tabel 3 diatas bahwa terlihat peningkatan dari hasil pretest dan posttest yang telah dilakukan sebelum dan sesudah proses pembelajaran. Hasil dari penelitian yang telah diperoleh yaitu bahwa kemampuan pemahaman konsep siswa kelas eksperimen dan kelas kontrol memiliki perbedaan yang signiikan. Berikut tabel peningkatan kemampuan pemahaman konsep matematis siswa pada Hal ini terlihat dari nilai rata-rata yang diperoleh pada kedua sampel, kelas eksperimen nilai rata-rata diperoleh 81,6 dan nilai rata-rata kelas kontrol diperoleh 75,58. Nilai tersebut menunjukkan bahwa kemampuan pemahaman konsep siswa kelas eksperimen setelah diberikan perlakuan 
pada proses pembelajaran lebih tinggi daripada kelas kontrol. Data yang telah terkumpul dapat dilakukan analisis data untuk menguji hipotesis. Pengujian hipotesis menggunakan kemaan dua rata-rata, rumus statistik yang digunakan adalah rumus uji-t. Berikut hasil uji hipotesis yang telah diperoleh

Tabel 4. Hasil Uji Hipotesis $N$-gain

\begin{tabular}{|c|c|c|c|c|c|}
\hline Kelompok & Rata-rata & Varians & $t_{\text {hitung }}$ & $t_{\text {tabel }}$ & Keputusan \\
\hline Eksperimen & 0,72 & 0,011 & \multirow{2}{*}{3,783} & \multirow{2}{*}{1.994} & \multirow{2}{*}{$\mathrm{H}_{0}$ ditolak } \\
\hline Kontrol & 0,64 & 0,007 & & & \\
\hline
\end{tabular}

Berdasarkan Tabel 4, terlihat bahwa dengan taraf signifikasi $\alpha=$ 0,05 diperoleh nilai $t_{\text {hitung }}=3,783$ dan $t_{\text {tabel }}=1.994$ dengan taraf signifikasi $\alpha=0,05$ karena $t_{\text {hitung }}>$

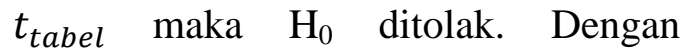
demikian dapat disimpulkan bahwa kemampuan pemahaman konsep matematis siswa dengan strategi The Firing Line lebih tinggi dari model pembelajaran biasa.

Proses pembelajaran menggunakan strategi The Firing Line di awal pertemuan pada kelas eksperimen, siswa masih belum terbiasa dengan cara belajar menggunakan strategi The Firing Line sehingga terjadi kegaduhan didalam kelas yang mengakibatkan keadaan kelas kurang kondusif dalam kegiatan pembelajaran dan terdapat siswa yang menginginkan perhatian lebih dengan cara bertanya hal-hal lain diluar pembelajaran.

Pada pertemuan pertama, proses pembelajaran memiliki beberapa kendala. Untuk itu peneliti memberikan pengertian kepada siswa tentang proses strategi yang akan dilaksanakan dan melakukan beberapa hal untuk mengatasi beberapa kendala tersebut.

Pada pertemuan selanjutnya siswa sudah mulai terbiasa dengan menggunakan strategi The Firing Line, sehngga pada proses pembelajaran berkelompok berjalan dengan lancar, senang dan tenang dalam menyelesaikan soal yang telah diberikan.

Pada proses pembelajaran menggunakan strategi The Firing Line terlihat keterlibatan siswa yang mulai berani untuk mengemukakan pendapatnya mengenai materi yang sedang dipelajari, mereka juga mulai berusaha memahami konsep agar setiap anggota dalam kelompok dapat menjawab pertanyaan-pertanyaan yang akan diberikan pada penerapan strategi The Firing Line. Mereka akan bersaing dalam tiap kelompok untuk menjawab soal-soal tersebut. Pada tiap kelompok dapat mengumpulkan point sebanyakbanyaknya dari menjawab soal tersebut akan diberikan penghargaan kepada mereka yang aktif dalam proses pembelajaran.

Faktor yang menyebabkan siswa dengan pembelajaran The Firing Line memiliki peningkatan kemampuan pemahaman konsep matematis yang lebih baik dari pada siswa dengan pembelajaran konvensional, yaitu adanya perbedaan perlakuan antara kelas eksperimen (pembelajaran dengan strategi The Firing Line) dan kelas kontrol (model pembelajaran biasa).

Pada kelas eksperimen siswa lebih merasa nyaman dengan pembelajaran karena dalam proses pembelajaran yang dilakukan berkelompok yang heterogen, dan siswa dikelas eksperimen lebih siap dalam proses pembelajaran karena pada 
pembelajaran menggunakan strategi The Firing Line siswa ditekankan untuk belajar terlebih dahulu sebelum berangkat ke sekolah.

Kelebihan strategi The Firing Line diantaranya dapat meningkatkan keaktifan siswa dalam proses pembelajaran akan lebih beermakna sehingga siswwa mampu memutuskan apa yang akan dipelajari dan cara mempelajarinya (Siregar, 2011), proses diskusi yang dilakukan antar siswa akan menimbulkan penguatan diri dimana siswa akan memandang kemampuan yang ada di dalam dirinya sendiri sebagai siswa yang efektif (Hariyanto, 2016), selain itu, diskusi juga dapat melatih siswa untuk mengemukakan pendapatnya secara verbal serta melatih siswa untuk menghargai pendapat orang lain (Sanjaya, 2006).

Berdasarkan penjelasan di atas dapat disimpulkan bahwa terdapat perbedaan peningkatan kemampuan pemahaman konsep matematis siswa yang diberi penerapan pembelajaran menggunakan strategi The Firing Line dengan pembelajaran biasa. Peningkatan kemampuan pemahaman konsep matematis siswa dengan penerapan strategi The Firing Line lebih baik daripada pembelajaran biasa.

\section{KESIMPULAN DAN SARAN}

Berdasarkan dari hasil analisis data dan pembahasan maka dapat diambil disimpulkan bahwa terdapat adanya perbedaan peningkatan kemampuan pemahaman konsep matematis siswa yang diberi penerapan strategi The Firing Line dengan pembelajaran biasa. Peningkatan kemampuan pemahaman konsep matematis siswa dengan penerapan strategi The Firing Line lebih baik daripada pembelajaran biasa.

Saran yang dapat diberikan dari hasil penelitian ini adalah diharapkan kepada guru matematika dapat mencoba menerapkan pembelajaran dengan strategi The Firing Line sebagai alternati untuk mencapai tujuan belajar. Bagi peneliti lain selanjutnya diharapkan dapat menerapkan dan mengembangkan prembelajaran menggunakan strategi The Firing Line. Selain itu pemberian pujian, reward, kretiitas dan pengembangan media pada proses pembelajaran sangat diperlukan guna meningkatkan kemampuan pemahaman konsep matematis siswa.

\section{DAFTAR PUSTAKA}

Gusliani, R., Harismasn, Y., \& Pratiwi, M. (2013). Pengaruh Penerapan Strategi Pembelajaran Aktif Tipe The Firing Line Terhadap Pemahaman Konsep Matematis Siswa Kelas VIII SMP N 17 Padang.

Hariyanto, W. D. (2016). Pembelajaran Akti Teori dan Asesmen. Bandung: Remaja Rosdakarya.

Herawati, O. D. (2010). Pengaruh Pembelajaran Problem Posing Terhadap Kemampuan Pemahaman Konsep Matematika Siswa Kelas XI IPA SMA Negeri 6 Palembang. Jurnal Pendidikan Matematika , Vol. 4 No.6.

Kartini, V. D. (2014). Peningkatan Kemampuan Pemahaman Matematikdan Sikap Positif terhadapMatematika Siswa SMP Nasrani 2 Medan Melalui Pendekatan Possing. Jurnal Saintech , Vol. 06, No. 04, ISSN No. 2086-9681.

Murizal, A., Yarman, \& Yerizon. (2012). Pemahaman Konsep Matematis dan Model Pembelajaran Quantum. Jurnal 
Pendidikan Matematika, Vol. 1 No. 1. Universitas Negeri Padang.

Nara, E. S. (2011). Teori Belajar dan Pembelajaran. Bogor: Ghalia Indah.

Putra, R. W. (2016). Pembelajaran Matematika dengan Metode Accelerated Learning untuk Meningkatkan Kemampuan Penalaran Adaptif. Jurnal Pendidikan Matematika, Vol. 7, No. 2.

Rahmawati, N. K. (2017). Implementasi Teams Game Tournament dan Number Head Together ditinjau dari Kemampuan Penalaran Matematis. Jurnal Pendidikan Matematika, Vol. 8, No. 2.

Sanjaya, W. (2006). Strategi Pembelajaran Berorientasi Standar Proses Pendidikan. Jakarta: Kencana.

Silberman. (2014). Active Learning 101 Cara Belajar Siswa Aktif. Bandung: Nuansa Cendekia.

Ningsih, S.C. (2014). Efektivitas Model Pembelajaran Think-Talk-Write Dalam Meningkatkan Komunikasi Matematis Mahasiswa Pendidikan Matematika. AKSIOMA Jurnal Pendidikan Matematika FKIP Univ. Muhammadiyah Metro. Vol. 3, No. 2.

Sudarman, S. W. (2016). Efektifitas Penggunaan Metode Pembelajaran Quantum Learning terhadap Kemampuan Pemahaman Konsep Matematis Mahasiswa. AKSIOMA Jurnal Pendidikan Matematika FKIP Univ. Muhammadiyah Metro, Volume. 7, No 2.

Suwanjal, U. (2016). Pengaruh Penerapan Pendekatan Kontekstual Terhadap
Kemampuan Berpikir Kritis Matematis Siswa SMP. AKSIOMA Jurnal Pendidikan Matematika FKIP Univ. Muhammadiyah Metro. Vol. 5, No. 1.

Utari, V. (2012). Peningkatan kemampuan pemahaman konsep melalui pendekatan PMR dalam Pokok Bahasan Prisma dan Limas. Jurnal Pendidikan Matematika, Vol. 1 No. 1.

Wardhani, S. (2008). Analisis SI dan SKL Mata Pelajaran Matematika SMP/MTs untuk Optimalisasi Tujuan Mata Pelajaran Matematika. Yogyakarta: PPPPTK. 